\title{
THE NORTHERN SECURITIES CASE
}

\author{
James Wilford Garner, Ph.D.
}

University of Pennsylvania

The history of the conception, organization and undoing of the Northern Securities Company cannot fail to be of interest to students of transportation probletns and constitutional law.

The recent decision of the Supreme Court which restrains the company from carrying out its real purposes is generally regarded as one of the most important ever pronounced by that august tribunal. Opinions differ widely, however, as to the merits of the decision; some have gone so far as to say that it means more to the people of the United States than any other event which has happened since the Civil War; ${ }^{1}$ others assert with equal confidence that a more iniquitous decree was never made by a court. ${ }^{2}$ In this article an effort will be made to review the steps leading up to the organization of this remarkable corporation, the purposes for which it was formed, the various legal prosecutions which it underwent, the decision of the Supreme Court in its various bearings, and the perplexing question of readjustment following the decision.

\section{CONCEPtion ANd ORganization.}

The Northern Securities Company is a corporation formed under the laws of New Jersey in November, I90I, for the primary purpose of acquiring and holding a majority of the stock of the Northern Pacific Railway Company, a Wisconsin corporation, and a part of the stock, but not a majority (so the Company alleges) of the Great Northern Railway Company, a Minnesota corporation.

The ultimate purpose, it was asserted, was not to vest the control of the two railroad systems in one body with a view to suppressing competition, but to protect the Northern Pacific road from the destructive raids of a third system and for the creation and development of a great volume of trade among the States of the Northwest and between the United States and the Orient by

1 Remarks of Governor Van Sant, of Minnesota: Associated Press dispatch of March I $4^{\text {th }}$

2 Prof. C. C. Langdell: Harvard Law Review, vol. 16, p. 549.

(125) 
establishing and maintaining a permanent schedule of cheap transportation rates.

The Great Northern and Northern Pacific railroads are substantially parallel lines extending from Lake Superior through the States of Minnesota, North Dakota, Montana, Idaho and Washington to the Pacific Ocean, each connecting with lines of steamships at their termini on the Great Lakes and the Pacific Ocean. Their aggregate length exceeds ro,ooo miles and although separated at most points by an intervening country hundreds of miles in extent, they touch at several places, notably Duluth, St. Paul, Fargo, Helena, Spokane, and Seattle. The total amount of their interstate traffic which may be said to be distinctively competitive, is relatively small. Mr. Hill testified that it did not exceed ten per cent. $^{3}$ while counsel asserted that it did not exceed three per cent. ${ }^{4}$ and this the Government did not deny, but asserted that even if the minimum estimate were true the total amount of traffic affected would approximate $\$ 800,000$ per year. ${ }^{5}$ Whatever may be the actual facts as to this point, the Supreme Court had already decided in a previous case that the two roads were parallel and competing lines. ${ }^{6}$ Both have competitors in the Union Pacific Railroad on the South and the Canadian Pacific Railroad on the North, each of which extends to the Pacific Ocean, and the latter of which touches at St. Paul.

The policy of the Great Northern Railroad since 1893 has been determined mainly by Mr. James J. Hill and his associates, not through the ownership of a majority of the stock, for they have never owned more than one-third of the total, but by reason of the implicit confidence which the stockholders have reposed in Mr. Hill's remarkable ability and success. ${ }^{7}$ The destinies of the Northern Pacific since its reorganization in 1896 have been mainly controlled by Mr. J. P. Morgan and his associates, who have acted in concert with Mr. Hill in matters affecting the interests of both systems. The first instance of this joint action was in 1896, when Mr. Morgan,

3 Record, pp, 714, 715.

- Mr. Young's brief, p. 7; Mr. Grover's brief, pp. 4-7.

5 Brief for the United States, p. Ir; Mr. John G. Johnson, of Counsel for the defendants. thought as much as 25 per cent. of the interstate traffic of the two roads is nominally competj. tive, but that more than one-fifth of this could be transported by other systems. - (Johnson's brief, p. 5.)

- Pearsall vs. Great Northern Railway, 161 U. S., 646.

7 Record, p. 698. 
in effecting a reorganization of the Northern Pacific, entered into an arrangement with Mr. Hill by which the stockholders of the Great Northern were to take over one-half the capital stock of the Northern Pacific and to guarantee its bonds. This arrangement, however, was held to be a violation of the law of Minnesota which forbids the consolidation of parallel and competing lines of railroad, and the decision marks the first of the series of defeats which the Hill-Morgan interests have encountered in their efforts to establish a "community of interest" between the two roads. A second instance of the kind was a joint attempt early in I9or to purchase the Chicago, Milwaukee and St. Paul Railroad, but the negotiations fell through. A joint effort was then made to purchase the Chicago, Burlington and Quincy, an extensive system embracing about 8,000 miles, traversing the States of Illinois, Iowa, Missouri, Nebraska, Wyoming and Colorado. This effort was successful, the purchase price being $\$ 200$ per share, or about $\$ 216,000,000$ in all, payable in the joint bonds of the two companies. ${ }^{8}$ The motive alleged for the purchase was the desire to effect an arrangement by which west-bound freights could be secured for the empty lumber cars returning from the Mississippi Valley to the Pacific Coast, so as to reduce transportation rates on lumber and other heavy natural products from the far West. If markets for Fastern and Southern products could be created on the Pacific Coast and in the Orient, the problem of return freights for empty cars would be solved. To create this new trade it was necessary to give the Oriental importer assurance that the low transportation rates offered would be permanent. No such assurance, it was asserted, could be given if the Burlington road, which constituted an essential link in the connecting chain of transportation, might in the future be induced to make changes in its rates. ${ }^{9}$

Immediately after the purchase of the Burlington became known, those interested in the Union Pacific Railroad, chief of whom was Mr. E. H. Harriman, realizing the danger from a permanent competition which the transfer of the Burlington to the Hill-Morgan combination assured, made overtures for an allotment to them of a portion of the Burlington shares, but their request was denied. ${ }^{\text {10 }}$

${ }^{8}$ Mr. Young's brief, p. 3r.; brief for the United States, p. I7.

9 Mr. Johnson's brief, p. 7 .

$10 \mathrm{Mr}$. Hill's testimony, Record, p. 44-46. 
Thereupon ensued the "raid" of the Union Pacific or Harriman interests on the Northern Pacific shares, culminating in the memorable panic of May 9, rgor. They succeeded in acquiring a majority of the total capital stock of the Northern Pacific Company, but fortunately for the Hill-Morgan interests nearly one-half of this stock belonged to the preferred class and was subject to retirement at any moment before January 1,1917 . It was the mistake of the Union Pacific interests in buying preferred instead of common stock that saved the Hill-Morgan interests from losing control of the Northern Pacific. The retirement of the preferred stock and the purchase of additional shares of common by Messrs. Hill and Morgan still left them in possession of a small majority of the shares. But there was always the danger that this majority might be converted into a minority at any moment by changes of ownership resulting from the death or weakening of the allegiance of friendly shareholders.

The effect of the acquisition of a majority of the shares of the Northern Pacific by the Union Pacific interests, Mr. Hill asserted, would be to put its control practically in the hands of those who were hostile to its growth and development and destroy its value. The interests of the Great Northern shareholders, he asserted, would be similarly affected. ${ }^{11}$ To prevent the possibility of such a contingency in the future and to protect the Northern Pacific Company from the recurrence of future "raids," it was determined by Mr. Hill, Mr. Morgan and their associates to form a holding corporation to which should be transferred in full ownership the shares of the Northern Pacific Company held by Mr. Morgan and his associates as well as those held by Mr. Hill and his friends in the Great Northern. This would give the proposed company a majority of the Northern Pacific shares, but less than one-third of those of the Great Northern.

To use Mr. Morgan's language: "What I wanted to accomplish was to put that stock where it would be protected."12 It was first proposed to organize the holding company as a Minnesota corporation provided a territorial charter could be found which was beyond the power of legislative amendment, but a diligent search failed to find such an one. ${ }^{13}$ Organization under the general laws of

11 Mr. Hill's testimony, p. 694.

$12 \mathrm{Mr}$. Morgan's testimony: Record, p. 344.

13 Colonel Clough's testimony: Record, p. 784 . 
the State of Minnesota was not favored because of the durble liability imposed on shareholders and the general unfriendliness of the State towards corporations. After an examination of the laws of West Virginia, New York, and New Jersey, the latter State was selected "principally because its incorporation laws were of earlier date and had been more thoroughly construed than those of other States." 14

On November 13, 1901, the projected company was incorporated under the name of the Northern Securities Company. It was agreed that its shares should be given in exchange for Northern Pacific shares on the basis of $\$ \$_{1} 15$ per share and for Great Norther1 stock on the basis of $\$$ I 80 per share, the price in both cases being somewhat less than the market value, a fact which is not without significance. The original plan was to capitalize the concern at an amount only sufficient to acquire a majority of the Northern Pacific stock and the holdings of Mr. Hill and his friends in the Great Northern which amounted to less than one-third of the total. Subsequently the scheme was enlarged so as to give all the shareholders an opportunity to sell their stock to the new company, not for the purpose, it was asserted, of acquiring a majority of the Great Northern stock, but to give all the shareholders the same opportunities that were given to Mr. Hill's friends. The capital stock of the Northern Securities Company was, therefore, fixed at $\$ 400,000,000$, the estimated amount necessary to take over at the exchange valuation agreed upon the entire capital stock of the Great Northern and Northern Pacific companies. Shortly after the organization of the company a considerable number of the "outside" holders of Great Northern stock upon the advice of Mr. Hill that they could do so with profit and advantage to themselves, accepted the offer of the Northern Securities Company and sold their holdings on the basis mentioned above. ${ }^{15}$ The result was that within a month after the organization of the Northern Securitics Company it had acquired about 76 per cent. of the entire capital stock of the Great Northern Railroad. A few weeks later the Union Pacific holders of Northern Pacific stock seeing that they were outdone sold their stock to $\mathrm{Mr}$. Morgan, receiving pay partly in cash and partly in Northern Securities stock, as a result

14 Mr. Young's hrief, p. 69; Mr. Grover s brief, p. 46.

15 Brief for the United States, p. 46; also Mr. Hill's letter: Record, p. $7 \circ 3$. 
of which the Northern Securities Company came into possession of about 96 per cent. of all the shares of the Northern Pacific. The effect was to place the control of the two roads in the hands of a single corporation, the Northern Securities Company, and to substitute in the place of two distinct sets of stockholders with rival and competing interests, one set of stockholders with common interests, or, to use the language of the Court, "the stockholders of the two competing companies disappeared, as such, for the moment, but immediately reappeared as stockholders of the holding company which was hereafter to guard the interests of both sets of stockholders as a unit."

\section{The Sficurities Company in Court.}

Soon after the full import of the organization became knowi a conference of Governors and Attorneys-General representing the States directly affected was held, upon the suggestion of the Governor of Minnesota, at Helena (December 30 ) and it was decided that the State of Minnesota should bring suit under the Sherman Act against the Securities Company in the United States Supreme Court. Permission, however, to file a bill for this purpose was denied. The State of Minnesota then instituted proceedings in its own courts; the case was transferred to the United States Circuit Court and eventually carried to the Supreme Court, when a decision was rendered April II, I904, against the State on a ground of jurisdiction.

But the suit that was destined to result in the undoing of the Securities Company was that instituted on March 10, 1902, on belialf of the United States, in the Federal Circuit Court for the District of Minnesota. The case was heard before the four judges of the Eighth Circuit in accordance with the Act of February II, 1903, for expediting the hearing of anti-trust cases, which provides that such cases shall be heard before not less than three Circuit Judges of the Circuit in which the suit is brought and that appeals from them shall lie directly to the Supreme Court. On April 9, 1903, a unanimous decision was rendered holding that the acquisition by the Northern Securities Company of a majority of the Stock of the Northern Pacific and Great Northern roads was a combination or conspiracy in restraint of trade among the States, and a decree was issued prohibiting the company from acquiring further stock of the two 
roads, from voting stock already acquired, from receiving dividends thereon, and from exercising any control over either road. The defendant railroads were enjoined from permitting their stock to be voted to the Northern Securities Company or paying dividends to the Northern Securities Company. Subsequently one of the judges suspended that part of the decree which forbade the payment of dividends, pending an appeal to the Supreme Court, to which the case was now carried.

The several lines of argument upon which the defendants relied may be roughly grouped as follows:

First, the acquisition by the Northern Securities Company of a majority of the shares of the two defendant railroad companies was not a "contract, combination or conspiracy" in restraint of trade or commerce among the States nor a "monopoly" of such trade but simply a contract of purchase and sale in no way connected with interstate trade or commerce. An agreement among competing lines to fix rates as in the Trans-Missouri case, or an agreement among manufacturing concerns not to compete among theinselves for the sale of their products, as in the Addyston Pipe case, were true contracts in restraint of trade, but only by the wildest stretch of the imagination, they contended, could an agreement to acquire property be placed in the same category. Nor could it be said that there was any monopoly even though it were granted that the purpose of the "merger" was to suppress competition, since monopoly involves the idea of the exciusion of other supply. Therecould be no monopoly unless all the existing roads were acquired by the Securities Company and the building of others was forbidden.

Second, there was no evidence of intention upon the part of the defendants to restrain or monopolize trade among the States as charged by the Government. The underlying motive, they asserted, was not to suppress competition, but to protect from the hostility of an enemy an arrangement designed to create and extend commerce both among the States and with foreign countries. In support of this proposition it was shown that the lumber business had been enormously developed, that a large trade in cotton and steel products with the Orient had been created and that transportation rates had been considerably reduced-so much so that a loss of $\$ 1,000,000$ in net earnings had resulted. It was, for example, shown that flour was being 
transported from points in the Mississippi Valley to China, a distance of nearly 8,000 miles, at the rate of 80 cents per barrel, while the rate to New York from the same points, distances less than 1,500 miles, was fifty-five cents per barrel. ${ }^{16}$ The problem of return fteights had been solved and a large coal traffic between Illinois and the States traversed by the Great Northern and Northern Pacific lines had been developed, the result of which was to relieve the inhabitants of this region of dependence upon the distant mines of Pennsylvania. In short, from whatever point of view it was considered only results of the highest benefit to the public at large had followed the "merger" and although this did not prove the absence of criminal intent, it constituted a very strong presumption against such intent. The defendants insisted that if the mere act of acquiring the stock of the two roads itself constituted restraint the presence or absence of evil intent was immaterial, but if it did not and this seemed self-evident, and if such acquisition had not resulted in restraint and the contrary was conclusively proven by the defendants and was not denied by the government, then the existence of criminal intent was necessary to constitute an offense. The government took the position that both questions were inmaterial and the Court sustained the contention.

To the allegation of the government that the Securities Company had been able to acquire a majority of the shares of the Great Northern (Mr. Hill and his friends owned but twenty-seven per cent. of the total) only by the "advice, procurement and persuasion" of Mr. Hill, the defendants replied in effect that the Company never contemplated taking over any of the Great Northern stock except that owned by Mr. Hill and his friends, and in fact would have preferred not to admit "outsiders," but not wishing to expose themselves to criticism it was decided to allow them to exchange their shares for Northern Securities stock if they wished. Being applied to for advice Mr. Hill prepared a circular to be sent only to those making inquiries, stating that in his opinion the Northern Securities offer could be accepted with profit and advantage. ${ }^{17}$ Further than this there was no "advice, procurement or persuasion."

Third, the Northern Securities Company did not possess the

\footnotetext{
16 Mr. Johnson's brief, pp. L3-16; see also Mr. Grover's brief, pp. r05-109; Mr. Hill's testimony: Record, pp. 677-737; Mr. Young's brief, pp. 29-41.

$17 \mathrm{Mr}$. Young's brief, pp. 79, 80
} 
power to restrain the trade of either road. It was merely an investment company and was not engaged in the business of transportation. The two railroad companies still remained as separate corporations with separate boards of directors, and by the laws of Minnesota and Wisconsin, no person who was a director in one company could serve on the board of directors of the other. Each was left free to conduct its own business independently of the other and it was therefore immaterial who held the shares since the affairs of a corporation are managed not by the shareholders but by the directors. ${ }^{18}$ When it is remembered, however, that the election of the boards of directors of both roads was vested in the Securities Company this argument will be seen to have little weight.

Fourth, granting arguendo the contention of the Government that the Northern Securities Company had acquired the power to suppress the relatively insignificant amount of distinctly interstate traffic it did not follow that the power would be exercised. The mere possession of power to do wrong is not criminally reprehensible if not exercised. It is the abuse of power, and not the possession of it that the law condemns. The man who purchases a gun acquires the power to commit a crime, but it is the exercise of the power that is punishable. There is no identity between the power to suppress competition and suppression any more than there is between potentiality and actuality. Moreover, the failure to exercise the power for more than two years after acquiring it rather constituted a presumption that it would not be exercised.

Fifth. The power of Congress to regulate interstate commerce does not include the power to regulate the acquisition, transfer and ownership of shares of stock in corporations created under State 1aw. The defendants contended that the overt act which had been committed was nothing more than the acquisition by one State corporation of the shares of two other State corporations. It was only a transaction of purchase and sale which had no more to do with interstate commerce than did the purchase by a farmer of an additional farm or the acquisition by a manufacturer of a nejghboring factory or other enterprise. The corporations concerned being creatures of the State it necessarily followed that the power to determine who should own their shares of stock, the conditions under

13 Mr. Young's brief, pp. 101, 192, 196. 
which they should be held or transferred, the voting power which should attach to each, the liability of the shareholders, etc., belonged to the States which created them and to no other authority. ${ }^{18}$

Sixth. Still another line of argument which deserves more consideration than it has received was the contention of the defendants that the Sherman Act was not intended to include agreements to purchase railways or to acquire the shares of competing lines or to consolidations, inasmuch as Congress well knew that at the time of the enactment of the Anti-trust Law the greater part of the railway system of the country rested upon such combinations either expressly authorized or tacitly permitted by the States, some of them having existed many years. If, therefore, it had been the purpose of Congress to declare such arrangements illegal, their securities void, and the State legislation authorizing then to be unconstitutional, it would have been so declared in more specific language than is employed in the Sherman Act. Many "mergers" have occurred since the enactmont of the Sherman law and they have all been a matter of common knowledge. ${ }^{20}$ But in no instance has the Sherman law been invoked against one of them, although they have practically destroyed competition in the territories traversed by them. The explanation offered was, that in the judgment of the Government, they were not combinations directly in restraint of interstate commerce and consequently the Sherman Act had no application. The defendants in the Northern Securities Company insisted that if the act did not apply to those combinations it should not be construed to apply to theirs. ${ }^{21}$

Senenth. The Sherman Act was directed only against unreasonabie restraints of trade such as restrictions with regard to the place of carrying on trade, the amount to be done, the regulation of prices, the use of trade secrets, etc., and not against those incidental and reasonable restraints that were always regarded as unobjectionable at comnon law.

Eighth. The Sherman law being a criminal statute should be strictly construed, or at least should not be enlarged by construction.

10 Mr. Young s brief, pp. 227-237; Mr. Johnson's brief, pp. 60-67.

20 It was pointed out for example that of the six railroad and steamship lines between New York and Boston not one was free to compete with the others. Likewise the several originally competing lines between Washington and New York are now all under the control of a single road.

21 Mr. Young's brief, pp. 238-272. 
This being true, the first section should not be stretched so as to make criminal every agreement that merely tends to restrain trade or that merely confers power to restrain. ${ }^{22}$ To be brought under the condemnation of the Anti-Trust Act the agreement must be one which will of itself operate as a restraint and not one from which restraint results only as an incident of the ownership of property. This was the doctrine of the Hopkins case where it was said that the Sherman Act applied only to those contracts whose direct and immediate effect is restraint.

Ninth. The Government was not entitled to maintain this action for the conspiracy charged, if it ever existed, had accomplished its purpose and had come to an end before proceedings were commenced against the defendants. The overt act had already been done and could not, therefore, be restrained after its consummation. The relief which the Sherman Act affords is power to restrain executory acts and not those already executed.

\section{THE OpINION OF THE COURT.}

The arguments in the case were heard at Washington, December I $4^{\text {th }}$ and I $5^{\text {th }}$, and the decision of the Court was announced on March 14th. The decree of the Circuit Court was affirmed by a vote of five to four. Justice Peckham, who wrote the majority opinions in the Trans-Missouri and Joint Traffic cases, Chief Justice Fuller, who concurred in both of these opinions, and Justices Holmes and White, dissented in the present case. Neither Justice Peckham nor Chief Justice Fuller have undergone a change of view, as is sometimes asserted, but were forced to separate from their colleagues with whom they had concurred in the two preceding cases, on account of the presence of a new issue in the present case, namely, the right of Congress to regulate the ownership and control of property in State corporations. No such question as this was raised in either of the traffic cases, the main issue there relating, so far as the power of Congress was concerned, to agreements or arrangements among interstate railroads to regulate their rates and pool their traffic. Their positions in those cases and in this one are, therefore, not at all inconsistent. The prevailing opinion in the present case was written by Justice Harlan, who had written the dissenting opinion in the Knight case.

22 Mr. Young's brief, p. Ing. 
Brushing aside as immaterial various minor contentions of the defendants the Court went directly to what it considered the two main questions involved. These were, first, whether through the organization of the Northern Securities Company the power had been acquired to restrain or monopolize commerce among the States and, second, whether the application of the Sherman law could be extended to such cases as this one where the right of the individual to acquire and hold property in a State corporation was in issue. Without directly imputing bad motives to the defendants the Court declared that the effect of placing a majority of the shares of the stock of the two roads in the hands of a holding corporation, which the Court described as a "mere custodian," was to give it the power to control the operation of both roads in the interest of those who were the stockholders in the constituent companies, as much so for every practical purpose as if it had been itself a railroad corporation which had built, owned and operated both lines for the exclusive benefit of its stockholders. It necessarily resulted from this arrangement that the constituent companies ceased to be in active competition for trade and commerce along their lines as formerly, and became practically "one powerful consolidated corporation, the principal object of which was to carry out the purpose of the original combination under which competition between the constituent companies would cease." No scheme or device, the Court thought, could more effectively suppress competition between the two roads, and that was enough to bring it under the ternis of the Sherman Act.

From this it will be seen that the Court took the position which the defendants had vigorously denounced as untenable, namely that under the Sherman Act the mere acquisition by the Securities Company of the stock of the two roads in question was in itself a contract, combination or trust in restraint of trade among the States. It refused to consider this transaction as the mere preliminary step in an arrangement which might result in restraint, but treated the preliminary act as the thing itself that was prohibited. In other words, it refused to recognize in this particular case, at least, any distinction between that which restrains and that which may result in restraint; between cause and result; between the possession of power and the exercise of power; between actuality and potentiality. In acquiring the power to do the things made unlawful by the Sherman 
Act the Securities Company had in effect committed the forbidden act. The acquisition of the power to suppress competition being, in the opinion of the Court, forbidden by the Shcrman Act, neither goodness of motive nor proof that there had been no actual restraint could condone the offense.

The contention of the defendants that the Sherman Act was intended to prohibit only those restraints which are unreasonable at common law was also dismissed by the Court as immaterial since this question had already been passed upon by the Court in other cases and was, therefore, res adjudicata. To their contention that the Sherman law prohibited only those acts in direct and immediate restraint, and not such as were merely "incidental to the ownership of property" the Court in effect answered that it had become a settled rule in the interpretation of the Anti-Trust Act that its application was not restricted to those combinations which result or may result in a total suppression of commerce or in a complete monopoly, but included as well those which by their necessary operation tend to restrain or monopolize and to deprive the public of the advantages that flow from free competition.

Taking up the proposition toward which the defendants directed their strongest efforts, namely, that the fundamental question involved in this case was, whether the power of Congress over interstate commerce extends to the regulation of the acquisition, ownership and disposition of stock in railroad corporations created under State law merely by reason of their being engaged in such commerce, the Court undertook to show that such a statement of the issue was wholly misleading and unwarranted; that it was merely setting up men of straw to be easily stricken down: that there was no reason to suppose that Congress had intended to interfere with the ownership and control of stock in State corporations; and that the Court did not understand that the Government had made any such contentions. But, said the Court, the Government does contend that Congress may protect the ireedom of interstate conlmerce by any means that are appropriate and not prohibited by the Constitution and that no State corporation can stand in the way of the enforcement of the national will, legally expressed, by projecting its authority across the continent into other States. It was not so much a question of whether Congress may control State 
corporations as a question of whether State corporations may control Congress by interposing obstacles in the way of the exercise of its Constitutional powers. To admit that a State may endow one of its corporations with authority to restrain interstate commerce was to say that Congress, in exercising its power to regulate such conmerce, must act in subordination to the will of the States when exerting their power to create corporations. No such view, said the Court, could be entertained for a moment. So far as the Constitution of the United States was concerned, said the Court, the States may create corporations of every kind, authorize them to engage in commerce, foreign as well as domestic, regulate all the incidents of corporate existence to the exclusion of the power of Congress, but they cannot empower any person, corporation or combination to defeat the will of the United States expressed through its Constitution and the laws passed in pursuance thereof.

To avoid the appearance of imputing to the State of New Jersey conscious intent to endow the Northern Securities Company with power to violate the Sherman Act the Court took ocrasion to say in passing that nothing in the record tended to show that the authorities of New Jersey had any reason to suspect that those who took advantage of its liberal incorporation laws had in view a purpose to destroy competition between two great railway carriers engaged in interstate commerce in distant States of the Union. The contention of the defendants that the Securities Company was not a railroad corporation, but an investment company, and that the transaction complained of imported simply an investment in the stock of other corporations, the Court seemed to think was not seriously made. This view was declared to be wholly fallacious and inconsistent with the actual facts, since there was no actual investment whatever there may have been in form.

The Northern Securities Company, the Court intimated, was not organized in good faith, but was merely a contrivance, a custodian or trustee for affecting indirectly a purpose which could not be accomplished directly. The suggestion of counsel for defense that no effective relief could be granted, since the alleged combination had accomplished its object before the commencement of the suit, the Court likewise treated as unworthy of more than a passing notice. It would be a novel, not to say absurd, interpretation of 
the Anti-Trust Act, it was asserted, to hold that after an unlawful combination had been formed and had acquired the power to restrain commerce by suppressing competition and was proceeding to: use that power, it should be left in possession of such power with unobstructed freedom to exercise it.

The many suggestions made in the course of the arguments that an interpretation of the Anti-Trust Act in accordance with the views of the government would seriously interfere with legitimate business interests and work widespread financial ruin were treated by the Court as gratuitous assertions. Such predictions had been made by the defendants in all the preceding cases arising under the Act and in no instance had they been verified. They were, therefore, entitled to no weight in the decision of the present case. The judgment of the Circuit Court of Appeals was, therefore, confirmed.

Mr. Justice Brewer, while concurring in the judgment, felt constrained to reject some of the reasons on which it was sustained for fear, as he said, "that the broad and sweeping language of the Court might tend to unsettle legitimate business enterprises, encourage improper disregard of reasonable contracts and invite unnecessary litigation." Instead of holding that the Anti-Trust Act included all contracts in restraint of trade, reasonable or unreasonable, the ruling, he said, "should have been that the contracts involved in this case were unreasonable restraints of interstate trade and, as such, were within the scope of the Act." He based this opinion on the language of the title of the Act which showed that it was directed only against "unlawful restraints and monopolies" which, according to a long course of decisions at common law had reference to unreasonable restraints and not those "minor contracts in practical restraint of trade" which had always been upheld as reasonable. His idea was that there being no national common law Congress intended merely to engraft upon the jurisprudence of the United States that well understood part of the common law which related to monopolies and combinations in restraint of trade; and, unless. it clearly appeared from the language of the Act that a departure from the rules and definitions of the common law was intended, no such purpose should be construed. Furthermore, he expressed the opinion that the general language of the Act was limited by the 
inalienable right of the individual to manage his own property and make such investments as his judgment dictated. Applying this principle to the present case, he asserted that had Mr. Hill owned a majority of stock of the Great Northern Raslway Co. he could not by any Act of Congress be deprived of the right of investing his surplus capital in the purchase of Northern Pacific stock, although such purchase might give him control over both companies. That is, he should have the same right to purchase Northern Pacific stock which all other citizens have. In other words it was his idea that to be an unlawful restraint under the Sherman Act, there must be a combination of two or more persons; restraint, however great, by a single individual if the result of the exercise of his right of investment could not be objectionable. It is respectfully submitted that this view is not justified by a reasonable interpretation of that part of the Sherman Act which relates to monopolies.

However, the opinion of Justice Brewer on this point was obiter, as the right of a single individual to invest his means according to his own will was not presented in this case. Here was a combination of individuals, and the prohibition of such a combination, he admitted, was not at all inconsistent with the right of an individual to purchase the stock of a corporation.

The views of the dissenting Justices were expressed in two separate opinions, one written by Justice White, the other by Justice Holmes. Justice White laid down the proposition that the fundamental question involved in the case was, whether Congress has power to regulate the acquisition and ownership of property in State corporations, and on this he wrote a long, ingenious, and, it must be admitted, able argument. It is submitted, however, witl all due deference, that his premise was wholly erroneous, being due to a mental confusion of the right of the individual to acquire and own property with his right to enter into a combination for the purpose of violating a law of the United States. With such a premise it was not difficult to prove his point and he did so effectively. His opinion contained some extreme propositions and sweeping assertions, rather notable as effective displays of rhetoric than as logical deductions from the real question decided. Such was the statement that the contention of the majority was "absolutely destructive" of the reserved rights of the States and that upon 
the ruins of the Federal system would be erected a government " "endowed with arbitrary power to disregard the great guaranty of life, liberty and property and every other safeguard upon which organized civil society depends."

Justice Holmes addressed himself mainly to the question of whether, conceding the power of Congress in the premises, the Sherman Act applied to the present case. His argument against the contention of the majority on this point was, first, that the Sherman Act is a criminal statute and should not be construed to punish acts which have always been lawful unless it expressed its intent in clear and unmistakable language. The present act, he said, should be read as if the question were whether two small exporting grocers should be sent to jail. In the second place, he contended that the forbidden contracts and combinations in restraint of trade were those dealt with and defined by the common law. Contracts in restraint of trade at common law were contracts with a stranger for the purpose of restricting the freedom of the contractor; combinations in restraint of trade were those formed with a view of keeping strangers to the agreement out of the business. In the present case there was no attempt to exclude strangers to the combination from competing in the business which it carried on. The Sherman Act, he declared, was not aimed at community of interest arrangements, but was intended to prohibit contracts with a stranger to the defendants, business, such as that involved in the Trans-Missouri Freight Association. Thirdly, to say that "every contract in restraint of trade". and "every attempt to monopolize any part" of interstate commerce was punishable would, he said, send to prison the members of every partnership and the owners of practically every railroad, for there was hardly one that did not monopolize, in a popular sense, some part of interstate commerce. Such a view could have no other effect than to make eternal the bellum omnium contra omnes and disintegrate society so far as it could into individual atoms.

\section{The Problem of Readjustment.}

The decree of the Circuit Court, as affirmed by the Supreme Court, did not work a dissolution of the Northern Securities Company, did not, in fact, affect its legal status in the least, but only enjoined it from acquiring further stock or from voting that which it had. 
already acquired, or from exercising any control over either road; nor did it have any perceptible effect on the price of Northern Securities stock. Within a week after the decision its shares had risen eight points in the market. The decree did not, as was generally reported, command the return to the original stockholders of the two roads of the shares transferred by them to the Securities Company in exchange for its stock, but merely directed that nothing contained in the decree should be construed as prohibiting such return. That is to say, the decree was permissive rather than mandatory so far as the question of the return of the stock was concerned.

As the two railroad companies, however, were enjoined from paying dividends to the Securities Company on the stock which it had acquired from them nothing was left but to return it or suffer the loss of dividends. On March 22d, following the decision of the Supreme Court, a circular letter was sent to the stockholders announcing that the Directors had decided to continue the existence of the Company but to reduce its capital stock by 99 per cent., the remaining I per cent., amounting to about $\$ 4,000,000$ and consisting of securities other than Northern Pacific or Great Northern stock was to be retained until it should be decided to wind up the affairs of the Company.

The 99 per cent. representing stock acquired from the Great Northern and Northern Pacific railroads was to be returned to those who had given it in exchange for Northern Securities stock. This could be done in either of two ways, namely, by a pro rata method, each shareholder receiving back an equivalent of his Northern Securities holdings in the stock of both roads, or by returning to each shareholder the original stock held by him in one road. The Hill-Morgan interests adopted the first method. Figured on the basis of 180 for Great Northern and I 5 for Northern Pacific each holder of one share of Northern Securities Stock would get back $\$ 39.27$ of Northern Pacific stock and $\$ 30.15$ of Great Northern stock. This would amount in effect, not to a restoration of the status quo ante, but a redistribution, the effect of which would be to give each original nwncr of stock in one road a joint interest in both roads. The far-reaching consequences to the Harriman holders of this method of redistribution were soon apparent. It will be remembered that at the tine of the formation of the Northern Securities Company 
the Union Pacific interests represented by Mr. Harriman and his associates held a majority of the shares of stock in the Northern Pacific, which shares were acquired by the Northern Securities Company under circumstances which have already been described in the early part of this article. By the methods of redistribution proposed the Harriman interests instead of getting back their original Northern Pacific shares, and with it their control over the Northern Pacific, would get back a ratable proportion of Great Northern and Northern Pacific stock. This would leave them jointly interested in both roads without a controlling interest in either. At the readjustment conference which followed shortly after the announcement of the Supreme Court, the Harriman representatives protested against the proposed plan of redistribution as an evasion of the true intent of the decree, and being overruled by the Hill-Morgan interests, Mr. Harriman and Mr. Pierce, acting as trustees for the Oregon Short Line, an appendage of the Union Pacific, began, on April 3, proceedings in the United States Circuit Court in St. Paul asking the Court to direct the Northern Securities Company to return to the original shareholders of Northern Pacific stock the shares exchanged by them for Northern Securities stock instead of an equivalent of stock in both roads. The purpose, of course, was to enable the Union Pacific interests to secure control of the Northern Pacific road and was a renewal of the old fight which had been temporarily suspended by the truce resulting from the organization of the Northern Securities Company.

Both parties were represented by an array of counsel which for brilliancy and numbers even exceeded that which appeared in the case before the Supreme Court, and the legal contest which ensued was one of the sharpest of recent years.

The chief contention of the Harriman interests was that the res toration to each shareholder of the original shares which he had exchanged for Northern Securities stock was the most logical and reasonable scheme, and seemed to be most in accord with the decree of the Court and the principles of natural justice. It must be admitted that it looked more nearly to the reestablishment of the status quo, which, it would seem, should have been the chief end to be kept in view in effecting the readjustment. Moreover, it was contended that redistribution according to the Hill-Morgan plan 
would be merely to continue their control over the Northern Pacific and Great Northern roads which it was the purpose of the decree to prevent.

The contention of the Hill-Morgan shareholders was that the return of the stock on the basis of the plan proposed by the petitioners meant the return to the Harriman people of a majority of the stock of the Northern Pacific Company, the effect of which would be to put in the hands of the Union Pacific Railroad and the Oregon Short Line the absolute control of the Northern Pacific, a parallel and competing line. Furthermore, the right of the petitioners to ask for intervention of this kind was denied. Having participated in the acts of the Northern Securities Company, which had been: declared illegal, they now sought from the Court preferential treatment at the expense of the innocent. "The shares Harriman put into this corporation," said Mr. John G. Johnson, of counsel, "have becone merged and their identity is lost and who can identify them?" "Are there any other marks on them to show which ones were put in by Harriman?" "There have been 1800 transfers of stock and no one knows where the individual shares are." The United States was not a party in this suit but through the Attorney-General interposed an objection against the right of the Court to intervene, stating that it neither admitted nor denied the allcgations of the petition but stood on the decree as affirmed by the Supreme Court and was only concerned to see that it was faithfully observed by the defendants according to its terms.

The Court refused to intervene in the matter, chiefly on the ground, as reported, that the decree was wholly prohibitory, only enjoining certain things to be done, viz.: the voting of stock and the acceptance of dividends, and so long as these things were not done, further action by the United States was unnecessary. That is to say, the Circuit Court was concerned only with the observance of the decree and not with the manner of the distribution of property among its stockholders. It being intimated that this was a matter within the jurisdiction of the Courts of New Jersey no time was lost by those concerned in resorting thereto, and application for an injunction to prevent the execution of the Hill-Morgan scheme of distribution was filed before Vice-Chancellor Bergen at Jersey City by the Continental Securities Company. 
Whether in instituting these proceedings it was acting for the Harriman interests it is not quite clear; at least the latter disclaimed any knowledge of the suit. On April 25th, the application for the injunction was denied. Resort was then had to the United States Circuit Court for the District of New Jersey, and Harriman, Pierce and others secured a temporary injunction restraining the Northern Securities Company from carrying out its proposed distribution.

In the latter part of May elaborate arguments by distinguished counsel were heard by Judge Bradford on the application of the petitioners to have the injunction made permanent, but at the time this article went to press no decision had been rendered.

\section{Conclusions.}

The following observations and conclusions, based on a careful study of the various Federal cases arising under the Anti-Trust Act, and particularly the recent decision of the Supreme Court, are respectfully submitted:

First. That Congress by virtue of its power to regulate foreign and interstate commerce may forbid transactions of purchase and sale when in its judgment the result of such transactions is to confer upon two or more persons the power to destroy competition between competing railroads. In the exercise of this power it is immaterial whether the forbidden transactions are expressly authorized by State law or not, or whether the property involved is the stock of railroads engaged wholly in interstate commerce or not, or whether the said railroad companies are incorporated under the laws of the United States or of a State. Likewise it is immaterial whether the intent of the transaction is to restrain commerce or to create and develop new commerce, or whether the power to restrain is exercised or not, or whether if exercised the resulting restraint is reasonable or unreasonable, or whether direct and immediate or remote and incidental.

Second. The decision of the Court does not sustain, as is often asserted, the contention that Congress may regulate the acquisition, ownership and disposition of property of State corporations or any of the incidents relating thereto. What it does hold is that no State by virtue of its power to create corporations and regulate the 
acquisition and ownership of property may endow any person or corporation with power to interpose obstacles in the way of free trade ainong the States.

Third. The Anti-Trust Act should not be interpreted as forbidding those reasonable restraints which were never objectionable at common law. In fact, it would seem as if a majority of the Court have come around to this view. But as the contrary interpretation stands as the law, Congress should amend the Act so as to restrict its application to unreasonable restrants. Early in the last session of Congress Senator Foraker proposed an amendment with this end in view, but it did not meet the approval of the administration and was, therefore, dropped. As the statute is now interpreted, it is too sweeping and if strictly enforced will work injury to legitimate business interests. It is doubtful if the framers intended to enact such a statute and the debates show unmistakably that the members of the Senate Committee on Judiciary, notably Senators Edmunds, Hoar and George, who, perhaps, had as much to do with the framing of the law as any other members, understood that it merely enacted the old doctrine of the common law relating to restraints of trade.

Fourth. The Eastern "1nergers," embracing about 85 per cent. of the railway mileage of the United States, will not be disturbed by the Grovernment. This comforting assurance was given by the Attorney-General in an interview following the announcement of the decision of the Supreme Court. He declared that the Government during the prosecution of the Northern Securities Company refused to give any heed to the contention of the defendants that all the railroad "mergers" in the country were on trial, but insisted that it was the validity of the Northwestern "merger" only that was in issue. Having succeeded in suppressing this one the Government did not propose to run amuck. No explanation was given why this particular one was singled out for prosecution and the others allowed to go free.

Fifth. The refusal of the Circuit Court to intervene in the Hill-Morgan scheme for redistributing the shares originally given in exchange for Northern Securities stock leaves the Northern Pacific road in the hands of Mr. Hill and his friends.

It thus happens that although the original act of the Northern. Securities Company has been virtually suppressed, the "community of 
interest " arrangement which the Securities Company was designed to protect, still survives. It is, therefore, questionable whether after all anything of permanent value has been gained by the prosecution and the resulting decree of the Court. 